\title{
Estimation of Gene Effect for yield, yield Components and Foliar Diseases of Two Faba Bean Hybrids at Nubaria Region
}

\author{
Abou Zied .A.A. ${ }^{1}$ and Hala M. El-Gendy ${ }^{2}$ \\ ${ }^{1}$ Legumes Crops Department, Field Crops Institute, Agric.Res. Center (ARC), Egypt. \\ ${ }^{2}$ Plant Pathology Research Institute, ARC, Egypt.
}

\begin{abstract}
Two crosses of faba bean (Giza716xGiza40) and (Giza716xNubaria2), each represented by six population $\left(\mathrm{P}_{1}, \mathrm{P} 2\right.$, $\mathrm{F} 1, \mathrm{~F}_{2}, \mathrm{BC} 1$ and $\mathrm{BC}_{2}$ ) were tested for yield, yield components, growth attributes and two diseases (chocolate spot and rust). Heterosis in $\mathrm{F}_{1}$, which exhibited highly significant positive effects were detected for number of branches /plant, number of pod /plant, number of seed /plant, seed yield /plant and plant height in the two crosses over mid and better parents. Significant negative Heterosis effects were obtained for chocolate spot and rust diseases in the two crosses over mid parents. Highly significant positive values of inbreeding depression were detected for number of branches/ plant, number of pods/plant, number of seed /plant, seed yield /plant, 100-seed weight and plant height in both crosses. However, highly significant negative values of inbreeding depression were found for chocolate spot and rust diseases in the two crosses. Over dominance towards the higher parent were detected for number of branches/plant, number of pods/plant, number of seeds/plant, seed yield /plant and plant height in both crosses. It was also found that over dominance controls spot and rust diseases in the second cross. Additive gene effects were significant for all characters, excepted number of seed/plant and seed yield/plant in both crosses. Dominance effects were highly significant for all traits, excepted, seed yield/plant and plant height in both crosses and rust disease in second cross. Additive $\mathrm{x}$ additive, additive $\mathrm{x}$ dominance and dominance $\mathrm{x}$ dominance types of gene action were significant for most traits in both crosses, except, chocolate spot and rust disease. In both crosses, high heritability values in broad sense were detected for all traits which, ranged between 63.20 for rust disease and $85.32 \%$ for reaction to chocolate spot and for cross (Giza 716 X Giza 40). However, cross (Giza 716 X Nubaria2) had values ranged from $60.7 \%$ for reaction to rust to $70.93 \%$ for seed yield/plant in (Giza $716 \times$ Nubaria2). The values of heritability in narrow sense were detected for all traits which, ranged between 60.19 to $80.36 \%$ for resistance to rust and chocolate spot disease in first cross, respectively and between 59.36 and $68.42 \%$ for number of pods/plant and seed yield / plant in the cross (G.716 x Nubaria.2).The estimates of expected genetic advance from selection in $\mathrm{F}_{2}$ generation reflected low or moderate values for all studied traits in both crosses that ranged between $7.78 \mathrm{~cm}$ for plant height to 1.8 for rust disease in cross (Giza 716 X Giza 40) and between $8.13 \mathrm{~cm}$ for plant height to 1.84 for number of branches/plant in (Giza 716 X Nubaria2) cross.
\end{abstract}

Keywords: Gene effect, Faba bean, Yield, Yield components.

\section{INTRODUCTION}

Faba bean (vicia faba L.) is the fourth most important pulse crop in the world consumed as dry seed, green vegetable or as processed food. It is used as an important cheap source of high quality protein in human diet of developing countries. Dry seeds, haulm and dry straw are used as animal feed (Kumara and Van Leur 2011). The average cultivated area over the last five years (2012-17) was about 113,000 feddans with an average yield of 9.2 arddab/faddan. The total production of this is still limited and faills to cover the increasing local consumption. There is a prerequisite to enlarge the production by expansion in new reclaimed areas, which might signify the scope of cultivated lands (Khalafallah et al, 2008 and Bakry et al, 2011).

The incidence of foliar disease is one of the main factors responsible for reduced yield, particularly in the North Delta region of Egypt. Ibrahim et al, 1979 found that,Botrytis faba is one of the most important fungal pathogens attacking the leaves and the stem of faba bean (Vicia faba, L.) and causes severe yield losses. Mohamed 1982 reported that, natural infection with leaf spot and rust, caused yield losses ranged from 22 to $55 \%$ with an average of $39 \%$.More attention was given by breeder to build up resistant faba bean lines for chocolate spot and rust diseases. El-Hady (1988)illustrated the presence of dominant gene for resistance to chocolate spot disease in some faba bean crosses and that the additive gene effects were stable over a range of years and narrow sense heritability estimates ranged from $69 \%$ to $95 \%$. Mazia et al, (2016), found a severe losses in faba bean yield as affected by Botrytis faba. Mualouf et al, (2016), Sillero et al, (2017) and Beyene et al, (2018) found that, some genotypes might be recommended for use in breeding for chocolate spot and rust disease.

The aim of the present study was to evaluate genetic parameters of Faba bean crosses using six population (P1, P2, F1, F2, BC1, and $\mathrm{BC} 2$ ) model. Heterotic effect, inbreeding depression, broad and narrow-senses heritability, type of gene action, potency ratio and the genetic advance from selection were estimated.

\section{MATERIALS AND METHODS}

The present study was carried out in the winter seasons of 2014/2015, 2015/2016 and 2017/2018 
under insect proof cages at Nubaria Agricultural Research Station. Three faba bean cultivars were used in this study; i.e; Giza716, Giza 40 and Nubaria 2 (Table1)

Materials used in this recent study were derived from tow crosses; namely (Giza716 X Giza40) and (Giza716 X Nubaria2) made in the first season (2014/2015), in the second season $(2015 / 2016)$ hybrid seeds were planted as F1 plants for each cross, where, self-pollinated and backcrossed to both parents to obtain the $\mathrm{F}_{2}$ 's and the backcross seeds. At the same time, crosses between the parental cultivars were repeated to obtain $\mathrm{F}_{1}$ hybrid seed. In the third season (2016/2017), the six population of each cross $\left(P_{1}\right.$, $\mathrm{P}_{2}, \mathrm{~F}_{1}, \mathrm{~F}_{2} \mathrm{BC}_{1}$ and $\mathrm{BC}_{2}$ ) were panted in a randomized complete block design experiment with three replications. Each plot consisted of two rows for non-segregating population; i.e., $\mathrm{P}_{1}, \mathrm{P}_{2}$ and $\mathrm{F}_{1}$; four rows for backcrosses and eight rows for $\mathrm{F}_{2}$ generations. Each row was three $\mathrm{m}$. long, 60 $\mathrm{cm}$ width and $20 \mathrm{~cm}$ between hills. One seed per hill was planted at one side of the ridge. All recommended cultural practices were applied. The following data were recorded on guarded 30 individual plants for each non segregating population, 80 plants for each backcross and 130 plants for each $F_{2}$ population. The following characters were recorded; Number of branches/plant, Number of pods/plant, Number of seeds/ plant, 100-seed weight (g), Seed yield/ plant $(\mathrm{g})$, plant height $(\mathrm{cm})$, chocolate -spot and rust diseases. Gene effect estimates were determined using the six parameters model of Gamble (1962). The heterotic effects of $F_{1}$ crosses were estimated as percentage over mid and better parent (Mather and Jinkes1971). The inbreeding depression was calculated as the percentage of deviation of the $F_{2}$ from $F_{1}$ performance. The degree of dominance was determined by calculating the potence ratio according to (Mather and Jinks1971). Heritability in both narrow and broad senses were estimated according to procedure of Mather (1949).

Table 1: pedigree, origin and some characters ofthe three Faba bean cultivars

\begin{tabular}{|c|c|c|c|c|}
\hline Cultivars & Pedigree & Origin & $\begin{array}{l}\text { Disease } \\
\text { reactions }\end{array}$ & Characteristics \\
\hline Giza716 & Egypt,461/842/83X503/453/83 & \multirow{3}{*}{$\begin{array}{l}\text { FCRI, } \\
\text { ARC, } \\
\text { Egypt }\end{array}$} & $\mathrm{R}$ & $\begin{array}{l}\text { Early maturing, medium seeds, resistance to } \\
\text { foliar diseases and adapted for North Delta }\end{array}$ \\
\hline Giza40 & $\begin{array}{l}\text { An individual plant selection } \\
\text { from Rebaya40 }\end{array}$ & & H.S & $\begin{array}{l}\text { Early maturing, medium seeds, susceptible to } \\
\text { foliar diseasesand adapted for upper Egypt }\end{array}$ \\
\hline $\begin{array}{l}\text { Nubaria } \\
2\end{array}$ & ILB155 X Radiation 2095/76 & & H.R & $\begin{array}{l}\text { Early maturing, medium seeds, resistance to } \\
\text { foliar diseasesand adapted for North Delta }\end{array}$ \\
\hline
\end{tabular}

FCRI: Field crops research institute.ARC: Agriculture research center.

$\mathrm{HR}=$ High resistance to foliar diseases (chocolate spot and rust diseases)

$\mathrm{R}=$ Resistance to foliar diseases chocolate spot and rust diseases)HS=High susceptibility to foliar diseases (chocolate spot and rust diseases)

Table 2: Rating scale for chocolate spot and rust diseases according Bernier et al. (1984).

\begin{tabular}{cl}
\hline Rate & \multicolumn{1}{c}{ Chocolate spot scale } \\
\hline 1 & No disease symptom (highly resistant) \\
\hline 3 & Few small discrete lesions (Resistant) \\
\hline 5 & Some coalesced lesions with some defoliation (moderately resistant) \\
\hline 7 & Large coalesced lesions, 50\% defoliations, some dead plants (susceptible) \\
\hline 9 & $\begin{array}{l}\text { Extensive lesions on leaves, stems and pods, severe defoliation, heavy sporulation, death of more than } \\
80 \% \text { of plants (highly susceptible) }\end{array}$ \\
\hline & Rust scale \\
\hline 1 & No pustules or very small non- sporulating flecks (high resistant) \\
\hline 3 & $\begin{array}{l}\text { Few scattered pustules covering less than 1\% of the leaf area, and few or no pustules on stem } \\
\text { (resistant) }\end{array}$ \\
\hline 5 & $\begin{array}{l}\text { Pustules common on leaves covering 1-4\% of leaf area, little defoliation and some pustules on stem } \\
\text { (moderately resistant) }\end{array}$ \\
\hline 7 & $\begin{array}{l}\text { Pustules very common on leaves covering 4-8\% of leaf area, some defoliation and many pustules on } \\
\text { stem (susceptible) }\end{array}$ \\
\hline 9 & $\begin{array}{l}\text { Extensive pustules on leaves, petioles and stem covering 8-10\% of leaf area, many dead leaves and } \\
\text { several defoliation (highly susceptible). }\end{array}$ \\
\hline
\end{tabular}




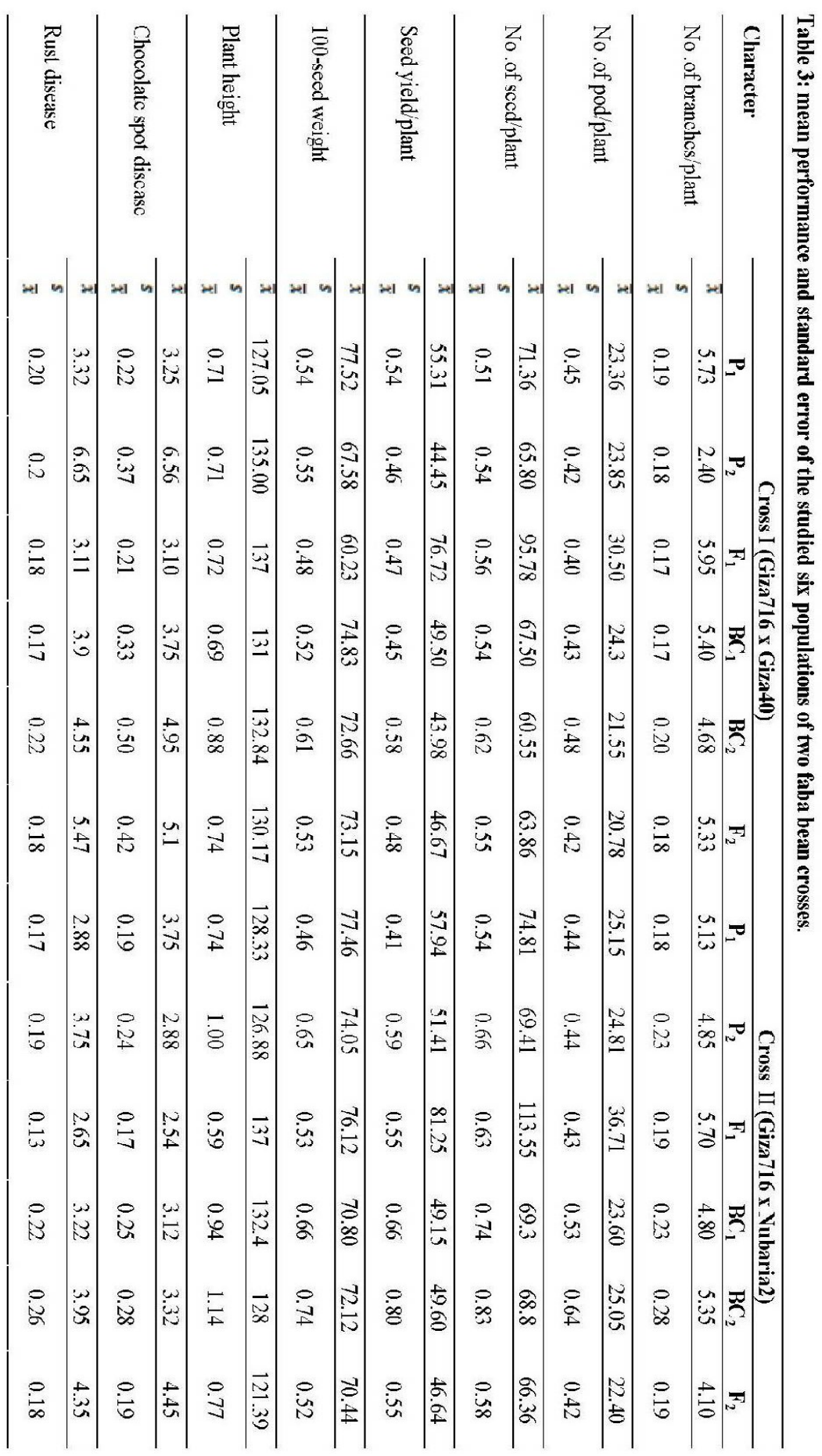




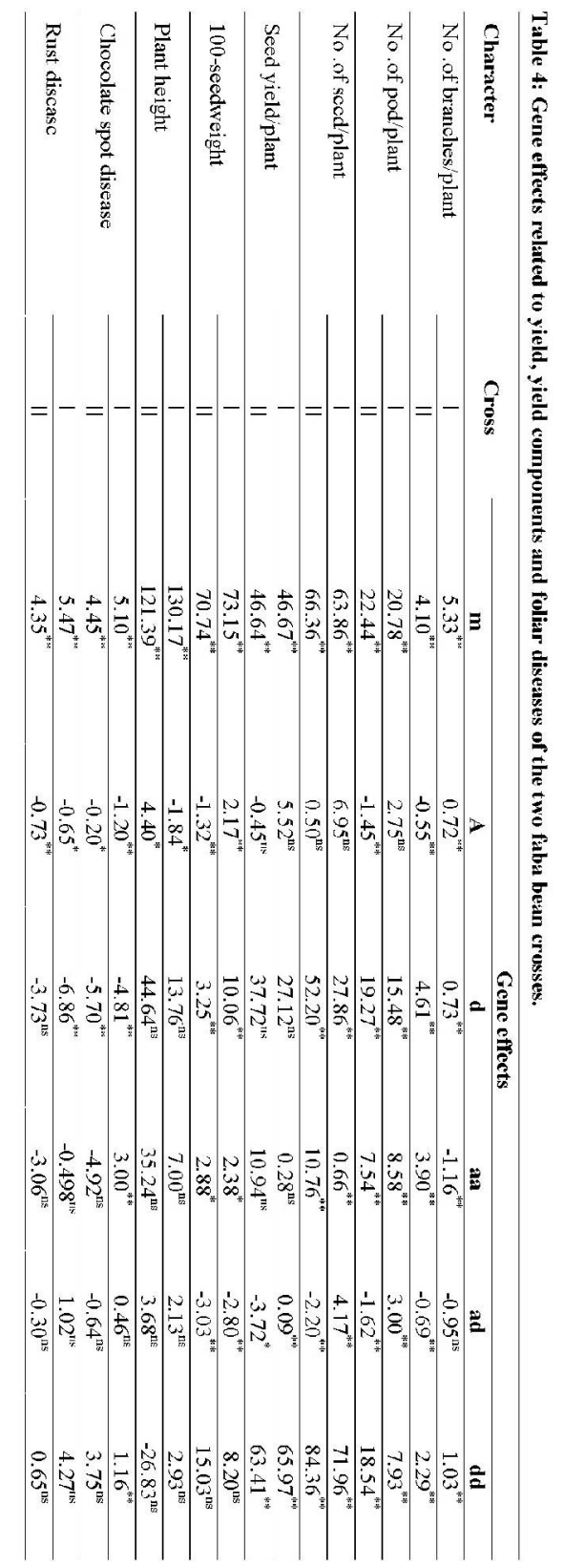




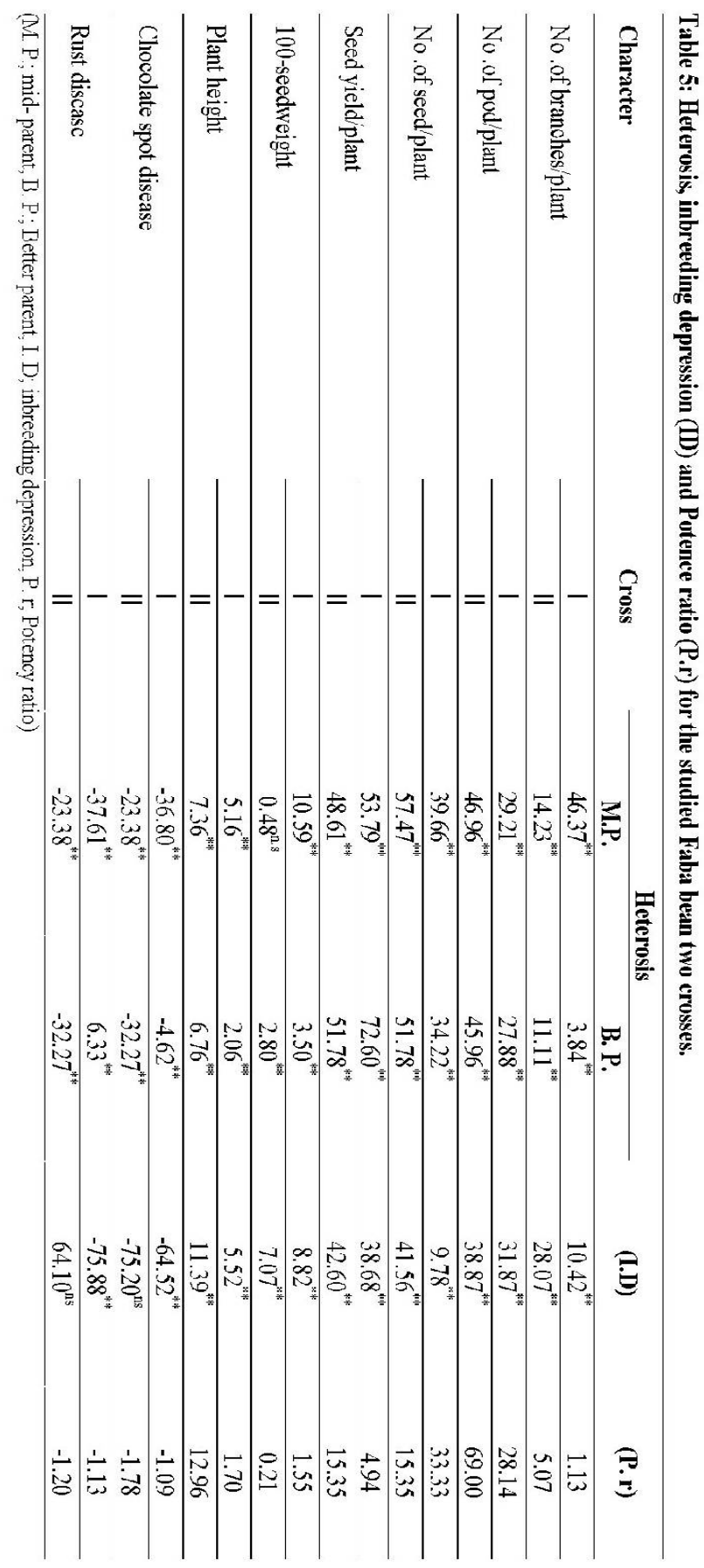




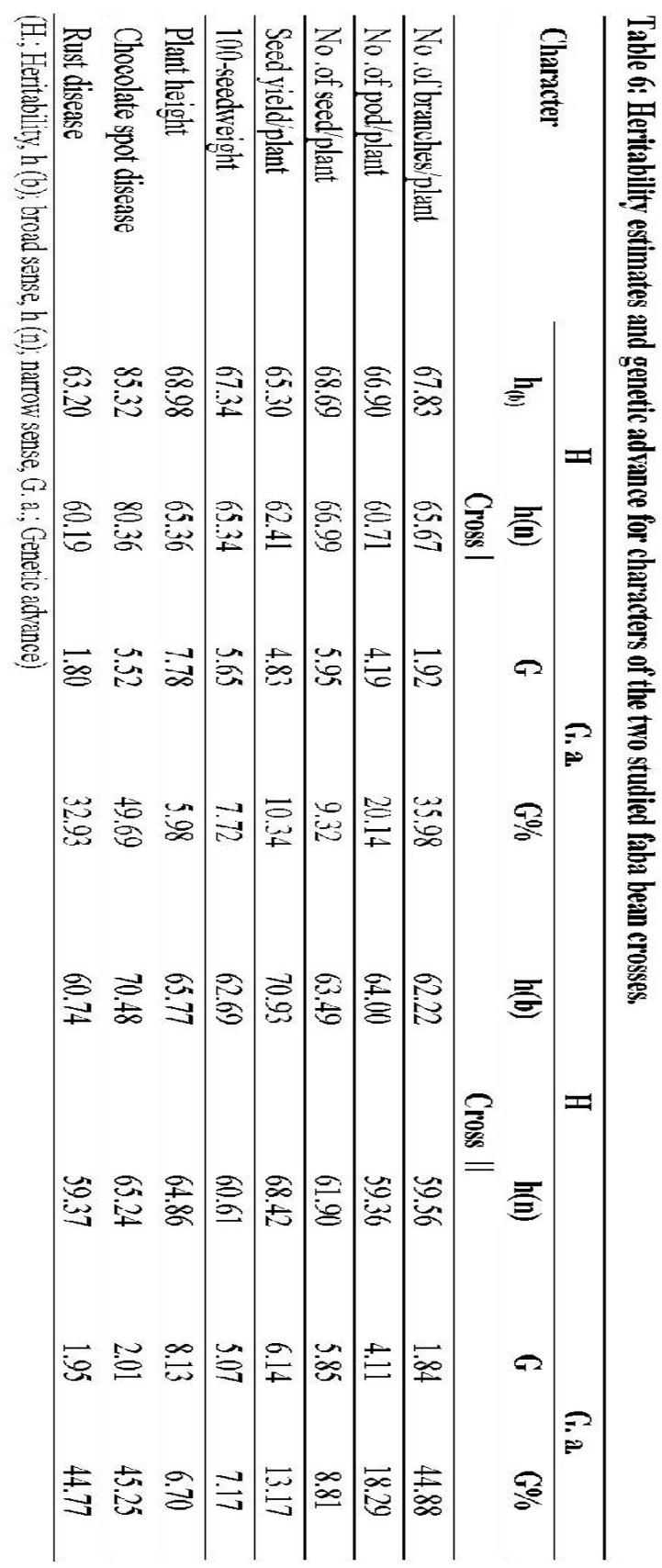


The predicted genetic advance from selection was estimated according to Johanson et al,(1955). Reaction to foliar diseases i.e.; chocolate spot and rust diseases was recorded on mid-February and mid-March, respectively according to the disease scales suggested by Bernier et al. (1984) as presented in Table (2).

\section{RESULTS AND DISCUSSION}

The mean performance and standard error of the studied traits in the six population among the two studied crosses were shown in Table (3). All characters in the two crosses indicated the presence of genetic variability and therefore detailed analyses of gene action could be done. The $\mathrm{F}_{1}$ means for yield and yield component characters were higher than those of both parents, this was reflected in the appearance of positive highly significant Heterosis. The $F_{1}$ means of cross (Giza $716 \mathrm{X}$ Nubaria2) were higher than the other cross for most traits. Also table (3) recorded chocolate spot disease score from 3.10 for cross(Giza $716 \mathrm{X}$ Giza 40) to 4.05 for cross(Giza 716 X Nubaria2)in F1's generation. The rust disease recorded score from 6.65 for cross (Giza 716 X Giza40) to 3.11for cross (Giza 716 X Nubaria2).

The estimated values of the six parameters describing the nature of gene action (Table 4). The estimated mean effect (m) which reflects the contribution due to the overall mean plus the loci effects and interaction of the fixed loci was highly significant. The additive effect (a) was highly significant in all traits, except, number of pod/plant and seed yield/ plant for the two studied crosses. The dominance effect (d) was highly significant or significant for all traits in the two crosses, except, seed yield/plant that was insignificant in both crosses. The interaction between additives $x$ additive (aa) was also highly significant for most traits, except, seed yield/ plant, plant height and reaction to rust resistant that were insignificant in the two studied crosses. The additive $\times$ dominance effect (ad) was highly significant for all traits of crosses, except, plant height and chocolate spot disease and rust disease in both crosses. The dominance $\times$ dominance (dd) effect was also highly significant for all traits in both crosses, except, 100-seed weight, plant height, chocolate spot disease and rust disease in the two studied crosses.

Heterosis over mid and better parents, inbreeding depression and Potenceratio for the studied characters were presented in Table(5).

Highly significant positive heterotic effects over mid and better parent were detected for all traits in both crosses, except, 100-seed weight in (Giza716 X Nubaria2) cross over mid-parents that was insignificant. Moreover, highly significant negative heterosis effects over mid- parents were obtained for chocolate spot and rust diseases in the two studied crosses. Better parent heterosis was also insignificant for cross (Giza $716 \mathrm{X}$ Nubaria2). The results of heterosis in this study were similar those reported by Abdalla et al.(2001), Attia et al. (2001), Attia and Salem (2006), El-Hady et al. (2006) and El-Hady et al. (2006).

As for inbreeding depression, highly significant positive values were obtained for all traits in both crosses, however, highly significant negative value was found for chocolate spot and rust disease in both crosses. Also, highly significant negative value were obtained for chocolate spot and rust diseases in both crosses. The results of inbreeding depression were in accordance with those of heterosis, and this was expected, since, the heterosis in $\mathrm{F}_{1}$ was always followed by $F_{2}$ depression. Similar over dominance towards the higher parent was found for number of branches/plant, number of pods/ plant, number of seeds / plant, seed yield/plant and plant height in both crosses, 100- seed weight for cross (Giza $716 \times$ Giza 40) and chocolate spot disease for cross (Giza $716 \times$ Nubaria2). However, over dominance towards the lower parent was detected for rust disease in cross(Giza $716 \times$ Nubaria2), results were in agreement with those obtained by Attia and Salem (2006), El-Hady et al, (2006), and Ibrahim et al, (2018).

Heritability values are important to the breeder, since, it quantifies the expected improvement upon selection. To achieve genetic improvement through selection, heritability must be reasonably high. In the present study, heritability estimates in broad and narrow sense and genetic advance as a percentage of the $\mathrm{F}_{2}$ character mean for the studied tow crosses were presented in Table (6). Similar results were obtained by El-Galaly (1997), El-Hosary et al, (1998), El-Refaey et al, (1999), El-Rodeny (2002)Attia and Salem (2006) and Ibrahim et al, (2018), Aboumoustafa (2003), El-Galaly(2003), Farag and Darwish (2005), Abd El-Maksoud et al, (2007) and El-Banna et al, (2013).This indicates that, when heritability estimates were high, the selection was effective in early generation, therefore additive gene effects were thought important.

\section{REFERENCES}

Abd El-Maksoud, M.M., M.S. Hmada, M.I. Amerand W.M. El-Rodeny (2007). Genetical analysis of some Vicia faba genotypes for tolerance to Orbanche infestation. Proceed. Fifth Pl. Breed. Conf. May 27 (Giza) Eygpt. J. Plant Breed. 11 (2):887-898, Special Issue.

Abou Moustafa, R.A. (2003).Genetical and biochemical studies on faba bean (Vicia faba L.). Ph. D. Thesis, Fac. of Agric, Moshtohor, Zagazig University., Egypt. $138 \mathrm{pp}$. 
Attia, S.M. and M.M. Salem (2006). Analysis of yield and its components using diallelmatings among five parents of faba bean. Egypt. J. Plant Breed 10: 1-12.

Bakry, B.A, T.A. Elewa, M.F. El karamany, M.S. Zeidan and M.M. Tawfik(2011). Effect of row spacing on yield and its components of some faba bean varieties under newly reclaimed sandy soil condition. World Journal of Agricultural Science, 7(1): 6872.

Bernier, C.C., S.B. Hanounik, M.M. Hussein and H.A. Mohamed (1984). Field manual of common faba bean diseases in Niel Valley. Information Bulletin No. 3. ICARDA, P.O Box 5466, Aleppo, Syria.

El-Banna, M. N, M.A.A Nassar, A.K.Nasrallah, M. M. EL-Hadyand A.A Abouzied (2013). Variability and Gene Action for Earliness and Yield componentsof Some Faba Bean Hybrids at NubariaRegion.PH.D.Thesis, fac. Of Agric. (Saba Basha) Alexandria, Univ. Vol. 18(3)459-509

El-Galaly, O. A. M. (1997).Genetical and serological studies on Vicia faba and nitrogen fixing bacteria. Ph.D. Thesis, Fac. Agric., Minufiya University, Egypt.

El-Galaly, A.M. Ola (2003). Generation mean analysis of yield and some of its components in faba bean (Vicia faba L.). J. Agric. Sci. Mansoura Univ., 28(3): 16731683, 2003.

El-Hady, M.M., Sabah, M. Attia, A.M. ElGalalyOla and Manal M. Salem (2006). Heterosis and combining ability analysis of some faba bean genotypes. J. Agric. Res. Tanta Univ. 32 (1): 134-148.

El-Hady, M.M. (1988).Diallelanalysis of resistance to chocolate spot disease (Botrytis fabae, Sard) and other agronomic traits in faba bean (Vicia faba L.). Ph.D.Thesis, Fac. Agric, Cairo Univ.

El-Hosary, A.A.; M.H. Bastawisy and M.H. Tageldin (1998). Heterosis and combining ability for yield and its components, earliness, total shedding and resistance to diseases and insects in faba bean (Vicia faba L.). Proc. 8th Conf. Agron., Suez Canal Univ., Ismailia, Egypt, 28-29 Nov., 268-279.

El-Refaey, R.A. (1998).Generation mean analysis of earliness, yield and some of its components in three faba bean crosses. Minufiya J. Agric.Res.24: 409-424.
El-Rodeny, W.M. (2002).Genetically and biochemical studies on some Vicia faba cultivars and their relative to Orobanchecrenata. M.Sc. Thesis, Fac. of Agric., Kafr El-Sheikh, Tanta Univ., Egypt.

Farag, S.T. and I.H. Darwish (2005). Type of gene effects of some economic traitsin faba bean (Vicia faba L.). Proceed. Fourth Pl. Breed. Conf. March 5, (Ismailia), Egypt. J. Plant Breed. 9 (1)7790 Special Issue.

Gamble, E. E.(1962). Gene effects in corn (Zea mays 1.). I- Separation and relative important of gene effects for yield .Canad. J Plant Sci., 42:330-384.

Ibrahim, A.A.; A.M. Nossib and M. El-Sherbeeny. (1979). Production and Improvement of GrainLlegumes in Egypt. In "Food legume improvement and development, (eds.) G.C. Hawtin and GJ. ChancelbrJDRC Pub. 126 e Ottawa: 39-46.

Ibrahim, M.A.M., M.G. Hoda. El-Shaboury and E. Zeinab Ghareeb (1018). Estimating genetic parameters by using line $\mathrm{x}$ tester analysis for some faba bean agronomic traits. Egypt J. plant Breeding. 22 (2). 357-371.

Johanson, H.W., H.F. Robinson and R.E. Comstock (1955). Estimates of genetic and environmental variability in soybean. Agron. J. 47:314-322.

Khalafallah, A.A., K.M. Tawfik, and Z.A. Abd El- Gawad(2008). Tolerance of seven faba bean varieties to drought and salt stresses. Research Journal of Agriculture and Biological Science,4(2): 175-186.

Maalouf, F., S. Ahmed, K. Shaaban, B. Bassam, F. Nawar, S. Murari and A. Amri (2016). New faba bean Germplasm with multiple resistance to Ascochyta blight, chocolate spot and rust disease Euphytica, 211(2):157-167.

Mather, K.(1949). Biometrical Genetics.1st Editions Metheum and CO., London162pp.

Mather, K. and J.L. Jinkes (1971).Biometrical Genetics. $2^{\text {nd }}$ edi. Chamman and Hall Ltd., London $382 \mathrm{pp}$.

Mbaziza, A., N. O. Ben Youssef, M. Kharrat (2016). Effect of some chemical inducers on chocolate spot disease of faba bean in Tunisia. Journal of Crop Protection;2016. 5(4):541-552. 
Mohamed, H. A. (1982). Major disease problems of Faba Bean in Egypt. In faba bean Improvement, preceding of the international Faba Bean Conference, Cairo, March, 7-11, pp.
Sillero, J. C., M. M. Rojas-Molina, A. A. Emeran, M. Kharrat, J. Winkler and H. R. Khan (2017). Identification and multi- environment validation of resistance to rust in Vicia faba Crop and Pasture Science, 68(10-11):10131023.

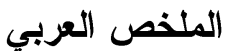

\section{تقدير الفعل الجيني للمحصول ومكوناته والامر اض الورقية لهجينين من الفول البلدي بمنطقة}

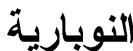

$$
\begin{aligned}
& \text { ابوزيد عبدالمحسن ابوزيد محمد'، هائه محمد رشاد الجندي' }
\end{aligned}
$$

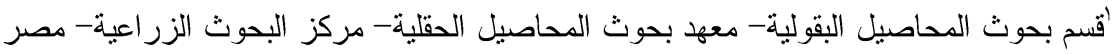

$$
\begin{aligned}
& \text { 'معهد بحوث امر اض النبات - مركز البحوث الزراعية. }
\end{aligned}
$$

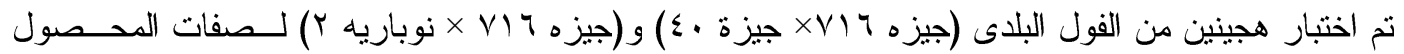
ومكوناته، صفات النمو، مرض التبقع البني ومرض الصدأ، تم تمثيل كل هجين بالعشائر الستة (الاباء و الجيل الاول

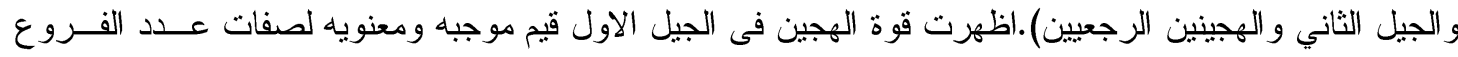

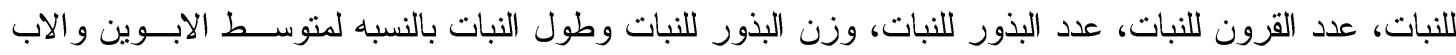

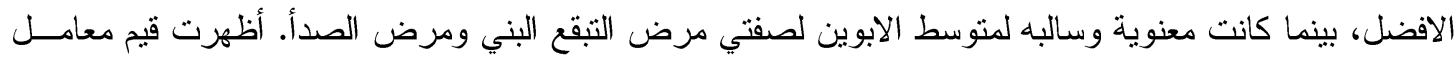

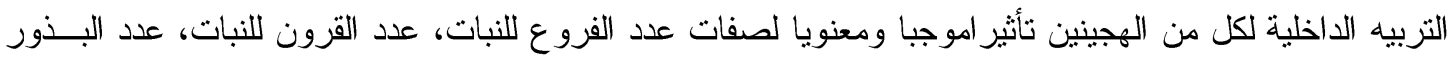

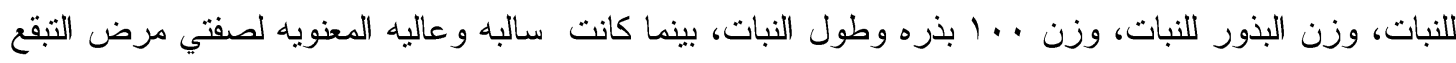
البني ومرض الصدأ لكل من الهجينين. أظهرت درجه السيادة وجود سيادة فائقه في اتجاه الاب الافضل لصفات عدم الافرع للنبــات، عـدد القــرون

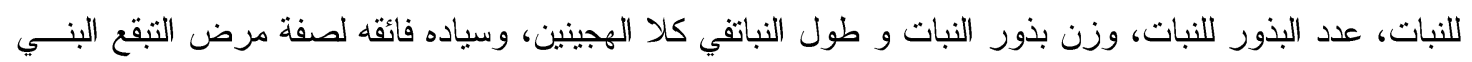

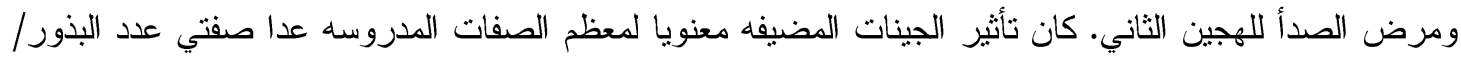
نبات ووزن محصول البذور للنبات فى كل من الهجينين وكان التأثير الجيني السيادي عالي المعنويه لكلا الهجينـين في معظم الصفات عدا صفات وزن البذور للنبات وطول النبات ومرض الصدأ للهجين الثانىكان غير معنوي وكذلك لكان

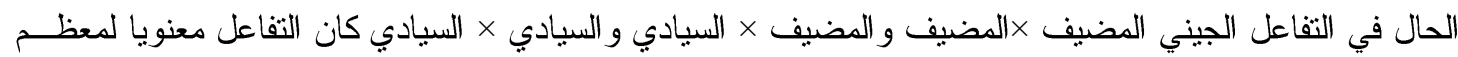
الصفات فى كل من الهجينين فيما عدا مرض التبقع البني ومرض وضئي الصدأ.

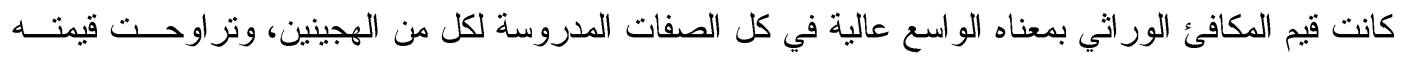

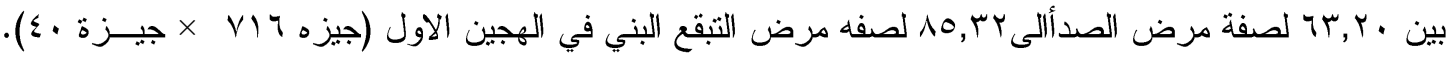

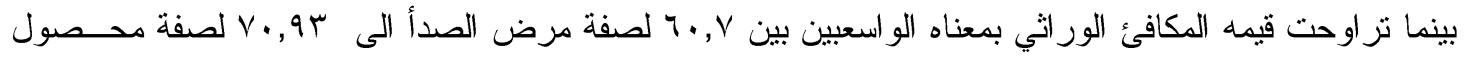

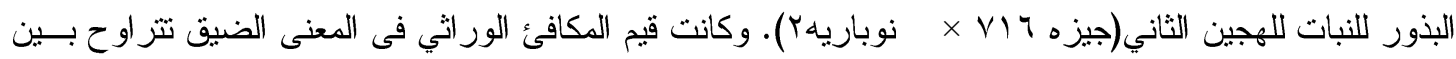

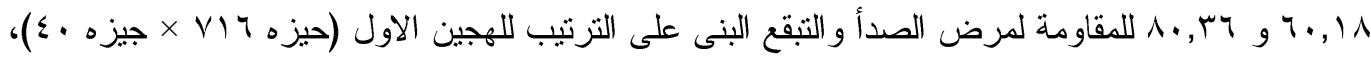




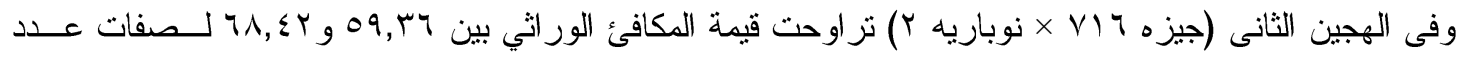

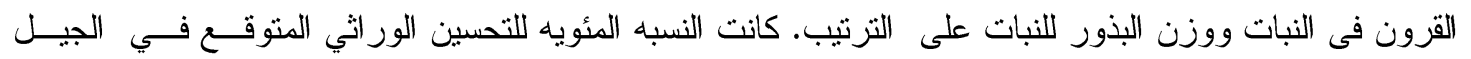
الثاني محدوده الى متوسطه لكل من الهجينين في كل الصفات المدروسه، حيث تراوحت القيمه بين ر, السم لصفة

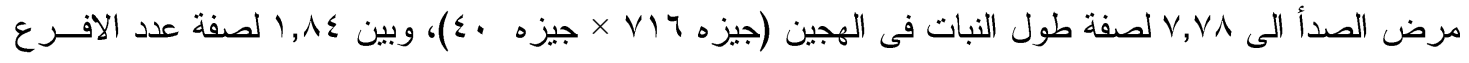

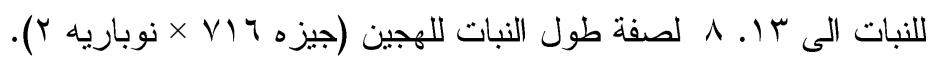

